\title{
Glucocorticoid and mineralocorticoid regulation of angiotensin II type 1 receptor binding and inositol triphosphate formation in WB cells
}

\author{
S G Shelat ${ }^{1}$, L M Flanagan-Cato ${ }^{1,2}$ and S J Fluharty ${ }^{1,2,3}$ \\ ${ }^{1}$ Institute of Neurological Sciences, University of Pennsylvania School of Medicine, Philadelphia, Pennsylvania 19104, USA \\ ${ }^{2}$ Department of Psychology, University of Pennsylvania, Philadelphia, Pennsylvania 19104, USA \\ ${ }^{3}$ Department of Animal Biology, University of Pennsylvania School of Veterinary Medicine, Philadelphia, Pennsylvania 19104, USA \\ (Requests for offprints should be addressed to S Fluharty, Department of Animal Biology, Rm 254E, University of Pennsylvania School of Veterinary Medicine, \\ 3800 Spruce Street, Philadelphia, Pennsylvania 19104, USA)
}

\begin{abstract}
Mineralocorticoids, glucocorticoids, and angiotensin II (AngII) act cooperatively to maintain body fluid homeostasis. Mineralocorticoids, such as aldosterone and deoxycorticosterone-acetate (DOCA), function synergistically with AngII in the brain to increase salt appetite and blood pressure. In addition, glucocorticoids increase AngII-induced drinking and pressor responses and may also facilitate the actions of aldosterone on salt appetite. The AngII Type 1 (AT1) receptor mediates many of the physiological and behavioral actions of AngII. This receptor is coupled to the G-protein Gq, which mediates AngII-induced inositol triphosphate (IP3) formation. The WB cell line, a liver epithelial cell line that expresses the AT1 receptor, was used to examine the cellular basis of glucocorticoid and mineralocorticoid regulation of AT1 function. In this study corticosterone and dexamethasone
\end{abstract}

treatments increased the number of AT1 receptors by activating the glucocorticoid receptor (GR). This increase in AT1 binding resulted in enhanced AngII-stimulated IP3 formation. However, only supraphysiological doses of aldosterone or DOCA increased AT1 binding, and this effect also was mediated by GR activation. Furthermore, despite evidence that mineralocorticoids and glucocorticoids function together to increase AngII-stimulated actions in vivo, aldosterone and dexamethasone did not act synergistically to affect AT1 binding, Gq expression, or IP3 formation. These results indicate that GR activation, and the subsequent increases in AT1 binding and in AngII-stimulated IP3 formation, may represent a cellular mechanism underlying the synergy between adrenal steroids and AngII.

Journal of Endocrinology (1999) 162, 381-391

\section{Introduction}

Angiotensin II (AngII), mineralocorticoids and glucocorticoids are important in maintaining cardiovascular and body fluid homeostasis. For example, AngII causes vasoconstriction, aldosterone and vasopressin release, and sodium reabsorption. It also acts in the brain to elicit water and salt intake (reviewed by Fluharty \& Sakai 1995). Although there are two subtypes of membrane-bound receptors that mediate the actions of AngII, the AngII type 1 (AT1) and the AngII type 2 receptors (Wong et al. 1992), the AT1 mediates most of the known physiological and behavioral actions of AngII (Fluharty \& Sakai 1995). Therefore, it is the focus of this study.

Mineralocorticoid treatment increases water intake, the pressor response (Wilson et al. 1986), and salt appetite (Epstein 1982, Fluharty \& Epstein 1983, Zhang et al. 1984, King et al. 1988) after central administration of AngII. Similarly, in conjunction with AngII, gluco- corticoid treatment increases AngII-induced pressor responses (Krakoff et al. 1975, Whitworth 1987) and drinking behavior (Ganesan \& Sumners 1989, Sumners et al. 1991). Adrenal steroids also increase AngII receptor binding in cultured vascular smooth muscle cells (Sato et al. 1992, 1994, Ullian et al. 1992), mesenteric arterioles (Schiffrin et al. 1984), brain (Wilson et al. 1986, King et al. 1988), and neuronal cultures (Wilson et al. 1986, Sumners \& Fregly 1989). These effects may provide a mechanism by which adrenal steroids augment AngII-mediated actions at the cellular level (Sato et al. 1992, Ullian et al. 1992, Thornton \& Nicolaidis 1994).

Intracellular receptors mediate the effects of mineralocorticoids and glucocorticoids. The mineralocorticoid receptor (MR) binds both aldosterone and corticosterone with high affinity $\left(K_{\mathrm{d}} \sim 0.5 \mathrm{nM}\right)$, whereas the glucocorticoid receptor (GR) preferentially binds glucocorticoids, although at lower affinity $\left(K_{\mathrm{d}} \sim 5 \mathrm{nM}\right)$ (Reul \& De Kloet 1985). However, when present in 
supraphysiological concentrations $\left(K_{\mathrm{d}} \sim 20-50 \mathrm{nM}\right)$, mineralocorticoids can activate GR (Claire et al. 1989, Schmidt et al. 1993). AngII receptor expression is modulated by endogenous steroids and synthetic analogs of the endogenous steroids, including dexamethasone, a highaffinity glucocorticoid agonist and deoxycorticosterone acetate (DOCA), a mineralocorticoid agonist (Sumners \& Fregly 1989, Vallee et al. 1995).

The present study examines the cellular basis of adrenal steroid regulation of AT1 receptor function. It was conducted in the WB cell line, a homogeneous population of liver epithelial cells that exclusively expresses the AT1 receptor subtype. The AT1 receptor is coupled to the G-protein, Gq , which mediates AngII-induced inositol triphosphate (IP3) formation (Taylor et al. 1990). The WB cell line has a well characterized IP3 pathway (Bokkala \& Joseph 1997) and is, therefore, an appropriate system with which to study the potential interaction of mineralocorticoids and glucocorticoids on AngII-induced IP3 formation. The initial experiments examined the steroid receptor specificity in mediating the effects of adrenal steroids on AT1 receptor binding, and subsequent experiments investigated the consequences on AngII signal transduction. Thus we examined whether these steroids might directly affect AT1 binding, Gq expression, IP3 formation, or combinations thereof, thereby amplifying the effects of AngII.

\section{Material and Methods}

\section{Cell culture and steroid treatment}

WB cells were maintained in Richter's minimal essential medium (Irvine Scientific, Santa Ana, CA, USA) containing $5 \%$ fetal bovine serum (Hyclone, Logan UT, USA), $20 \mathrm{mM}$ HEPES, $25 \mathrm{mM}$ sodium bicarbonate, $100 \mathrm{U} / \mathrm{ml}$ penicillin, $100 \mu \mathrm{g} / \mathrm{ml}$ streptomycin. Aldosterone, corticosterone, dexamethasone, and DOCA (Sigma, St Louis, MO, USA) and steroid antagonists RU38486 and RU28318 (kindly donated by Roussel-Uclaf, Romainville, France) were dissolved in 100\% ethanol, then serially diluted in medium at the concentration described. Final ethanol concentration was $0 \cdot 002 \%$.

\section{Membrane receptor binding}

WB cells were rinsed twice with ice-cold $20 \mathrm{mM}$ Tris$\mathrm{HCl}(\mathrm{pH} 7 \cdot 4), 150 \mathrm{mM} \mathrm{NaCl}$, then incubated for $10 \mathrm{~min}$ at $4{ }^{\circ} \mathrm{C}$ in $20 \mathrm{mM}$ Tris- $\mathrm{HCl}(\mathrm{pH} 7 \cdot 4)$, scraped with a rubber spatula, and homogenized with a Dounce homogenizer. The membrane suspension was centrifuged at $48000 \boldsymbol{g}$ for $20 \mathrm{~min}$. The membrane pellet was resuspended in buffer containing $50 \mathrm{mM}$ Tris- $\mathrm{HCl} \mathrm{pH} 7 \cdot 4$, $150 \mathrm{mM} \mathrm{NaCl}, 5 \mathrm{mM} \mathrm{MgCl}$, aprotinin $(0 \cdot 3$ trypsin inhibitory units $(\mathrm{TIU}) / \mathrm{ml}$ ) and 1,10 phenanthroline
$(0.1 \mathrm{mg} / \mathrm{ml})$, and homogenized. Membrane preparations were added to tubes containing $0.5 \mathrm{nM}{ }^{125}$ I-AngII (2200 Ci/mmol; NEN/Dupont, Boston, MA, USA), except for the saturation isotherm experiment, in which the concentration of ${ }^{125} \mathrm{I}$-AngII was in the range $0 \cdot 3-7 \mathrm{nM}$. The preparation was then incubated for $1 \mathrm{~h}$ at $22^{\circ} \mathrm{C}$, and binding was terminated by dilution with ice-cold $10 \mathrm{mM}$ Tris- $\mathrm{HCl}(\mathrm{pH} 7 \cdot 4), 150 \mathrm{mM} \mathrm{NaCl}$ and rapid vacuum filtration through $0 \cdot 3 \%$ polyethylenimine presoaked Whatman GF/B filters using a Brandell cell harvester. Dried filters were counted for $1 \mathrm{~min}$ in an LKB gamma-scintillation counter at $65 \%$ efficiency. Nonspecific binding was determined in tubes with unlabelled Sarlle $(1 \mu \mathrm{M})$ (Wong et al. 1992). Protein concentration was determined by the bicinchoninic acid (BCA) method (Pierce, Rockford, IL, USA). Triplicate values were averaged and calculated as specific fmol/mg protein. The 'vehicle-treated' level of AT1 binding in Fig. 4 differs from that of Fig. 2 because the latter value is a Bmax value calculated from a saturation binding experiment, whereas the former reflects binding carried out with a concentration of $0.5 \mathrm{nM}{ }^{125} \mathrm{I}$-AngII. In Figs 1, 3, and 5, where AT1 binding was expressed as '\% increase above vehicle,' the vehicle baseline binding values are shown in the figure legends.

\section{IP3 measurements}

IP3 assays were conducted as described previously (Bokkala \& Joseph 1997). WB cells were grown in Dulbecco's modified inositol-free medium (Life Technologies, Gaithersburg, MD, USA) and treated with $5 \mu \mathrm{Ci} / \mathrm{ml} \quad m y o-\left[{ }^{3} \mathrm{H}\right]$ inositol (American Radiolabelled Chemicals, St Louis, MO, USA) for $20 \mathrm{~h}$. The medium was then removed and replaced with media containing AngII for $30 \mathrm{~s}$. Cells were washed twice with phosphate

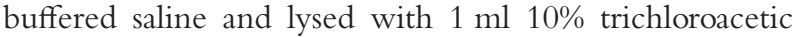
acid. The cell lysates were centrifuged and supernatants were extracted five times with two volumes of watersaturated diethyl ether. Protein determination of cell lysates were performed by the BCA method. The aqueous phase was neutralized with $600 \mathrm{mM}$ sodium bicarbonate and $300 \mathrm{mM}$ EDTA. Samples were run over AG 1-X8 columns (Biorad, Hercules, CA, USA) and inositol phosphates were sequentially eluted with increasing concentrations of ammonium formate. Radioactivity of fractions was measured with liquid scintillation counting (True-Count, IN/US systems).

\section{Western blot analysis}

Cells were rinsed twice with ice-cold $20 \mathrm{mM}$ Tris- $\mathrm{HCl}$ $(\mathrm{pH} \mathrm{7 \cdot 4)}, 150 \mathrm{mM} \mathrm{NaCl}$, then incubated for $10 \mathrm{~min}$ at $4{ }^{\circ} \mathrm{C}$ in $20 \mathrm{mM}$ Tris- $\mathrm{HCl}(\mathrm{pH} 7 \cdot 4)$, scraped with a rubber spatula, and homogenized with a Dounce 
homogenizer. The membrane suspension was centrifuged at $48000 \mathrm{~g}$ for $20 \mathrm{~min}$. The membrane pellet was resuspended in buffer containing $50 \mathrm{mM}$ Tris $-\mathrm{HCl} \mathrm{pH}$ 7·4, $150 \mathrm{mM} \mathrm{NaCl}, 5 \mathrm{mM} \mathrm{MgCl}$, aprotinin (0.3 TIU/ $\mathrm{ml}$ ) and 1,10 phenanthroline $(0 \cdot 1 \mathrm{mg} / \mathrm{ml})$, and homogenized and assayed for protein concentration by the BCA method. Membrane samples were boiled for $3 \mathrm{~min}$ in electrophoresis sample buffer, then subjected to SDS/10\% polyacrylamide gel electrophoresis, transferred to nitrocellulose filters, and nonspecific sites were blocked with $3 \%$ gelatin in Tris-buffered saline (TBS; $10 \mathrm{mM}$ Tris$\mathrm{HCl}, \mathrm{pH} 8 \cdot 0,150 \mathrm{mM} \mathrm{NaCl})$ overnight at $4{ }^{\circ} \mathrm{C}$. The blocking solution was discarded and replaced with $5 \%$ nonfat dry milk for $30 \mathrm{~min}$ at $22{ }^{\circ} \mathrm{C}$. The filters were incubated with a primary $\mathrm{Gq}_{\alpha}$ antiserum kindly provided by D Manning (University of Pennsylvania) in 1\% gelatin/ TBS $(1: 1000)$ for $90 \mathrm{~min}$ with gentle shaking at $22^{\circ} \mathrm{C}$. This antiserum has equivalent specificity for $\mathrm{Gq}_{\alpha 11}$ and $\mathrm{Gq}_{\alpha, \mathrm{q}}$, but not for $\mathrm{Gq}_{\alpha 15}$ or $\mathrm{Gq}_{\alpha 16}$ (Lounsbury et al. 1993). Blots were washed with TBS 0.05\%-Tween 20 (TBST) and then incubated with horseradish peroxidaseconjugated goat anti-rabbit IgG (New England Biolabs, Boston, MA, USA) in TBS $(1: 1500)$ for $60 \mathrm{~min}$. After TBST washes, the blots were developed by Phototope Western blotting reagents (New England Biolabs) as described by the manufacturer. Films were processed and analyzed using computer densitometry (NIH Image).

\section{Reverse transcription-polymerase chain reaction (RT-PCR)}

Total RNA from WB cells and adult Sprague-Dawley rats (Harlan, Indianapolis, IN, USA) anterior pituitary (Seltzer et al. 1992) was extracted using Trizol reagent (Life Technologies) according to the manufacturer's instructions. Ten micrograms total RNA were reversetranscribed using $\mathrm{M}-\mathrm{MuLV}$ reverse transcriptase (Pharmacia Biotech, Piscataway, NJ, USA) and $0 \cdot 2 \mu \mathrm{g}$ random primed hexamers for $37^{\circ} \mathrm{C}$ for $1 \mathrm{~h}$. The PCR reaction was carried out in $50 \mu \mathrm{l}$ volume with $5 \mu \mathrm{l}$ $10 \times$ PCR buffer II (Perkin Elmer, Foster City, CA, USA), $3 \mu \mathrm{l} 25 \mathrm{mM} \mathrm{MgCl} 2,4 \mu \mathrm{l} 2.5 \mathrm{mM}$ dNTPs, $1 \mu \mathrm{l}$ cDNA template, $50 \mathrm{ng}$ each MR primer, and $2.5 \mathrm{U}$ AmpliTaq-DNA Polymerase (Perkin Elmer). To avoid evaporation, mixes were overlaid with $50 \mu \mathrm{l}$ mineral oil. Amplification was performed over 30 cycles (30 s denaturing at $94{ }^{\circ} \mathrm{C}, 1 \mathrm{~min}$ annealing at $58{ }^{\circ} \mathrm{C}, 1$ min extension at $72^{\circ} \mathrm{C}$ ) in a DNA thermal cycler (Perkin Elmer Cetus). The $5^{\prime}$ and $3^{\prime}$ MR primers correspond to bp 4875-4901 and bp 5550-5524, respectively, of the rat MR mRNA coding sequence as described elsewhere (Patel et al. 1989). The identity of the amplified MR RT-PCR product (695 bp) was confirmed by EcoR1 restriction enzyme cleavage. The RT-PCR products were analyzed by $2 \%$ agarose gel electrophoresis, and visualized by ethidium bromide staining under u.v. light.

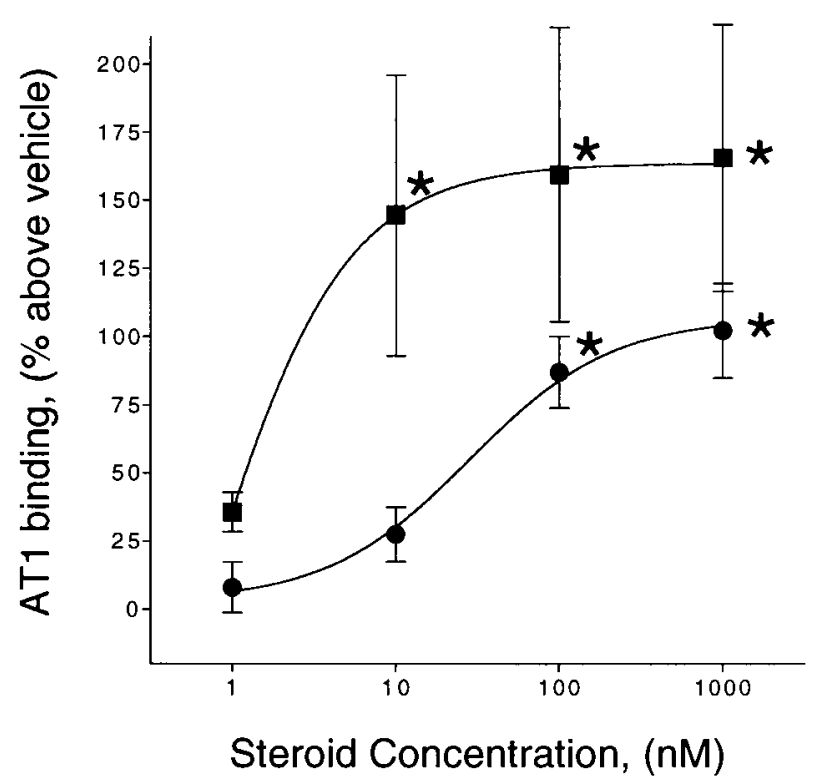

Figure 1 Effect of corticosterone $(\mathbf{0})$ and dexamethasone $(\boldsymbol{\square})$ on AT1 binding. Dose-response curve of corticosterone and dexamethasone on $0.5 \mathrm{nM}^{125} \mathrm{I}$-Angll binding. WB cells were treated with steroid at doses of $1-1000 \mathrm{nM}$ for $20 \mathrm{~h}$ before harvest. The data are reported as percentage increase in AT1 binding above that of vehicle-treated cells. The vehicle baseline AT1 binding was $408 \pm 121 \mathrm{fmol} / \mathrm{mg} ; n=5$, mean \pm S.D. ${ }^{*} P<0 \cdot 05$.

\section{Statistical analysis}

Results are represented as mean \pm standard deviation (S.D.). Statistical analysis was done via one-way ANOVA, followed by Student-Newman-Keuls' post hoc comparisons, with $P<0 \cdot 05$ considered statistically significant.

\section{Results}

The aim of this study was to determine the cellular basis of glucocorticoid and mineralocorticoid effects on AT1 binding and intracellular signalling. WB cells were treated with corticosterone and dexamethasone at doses of 1, 10, 100, and $1000 \mathrm{nM}$ for $20 \mathrm{~h}$ before harvest. The baseline AT1 binding in vehicle-treated cells was $408 \pm 121 \mathrm{fmol} / \mathrm{mg}$. Treatment with corticosterone increased ${ }^{125}$ I-AngII binding in a dose-dependent manner $(P<0 \cdot 05)$, maximally increasing AT1 binding $102 \pm 17 \%$ at the highest dose of $1 \mu \mathrm{M}$ corticosterone (Fig. 1). Similarly, treatment with dexamethasone significantly increased ${ }^{125}$ I-AngII binding $(P<0 \cdot 05)$, with a maximal increase at $165 \pm 48 \%$ above control. Dexamethasone was more effective at stimulating AT1 binding than corticosterone (dexamethasone $\mathrm{EC}_{50}=0 \cdot 21 \pm 0 \cdot 19 \mathrm{nM}$; corticosterone $\mathrm{EC}_{50}=$ $41 \cdot 7 \pm 17 \mathrm{nM}, n=5)$.

In subsequent experiments, radioligand binding techniques were used to examine whether the stimulatory 


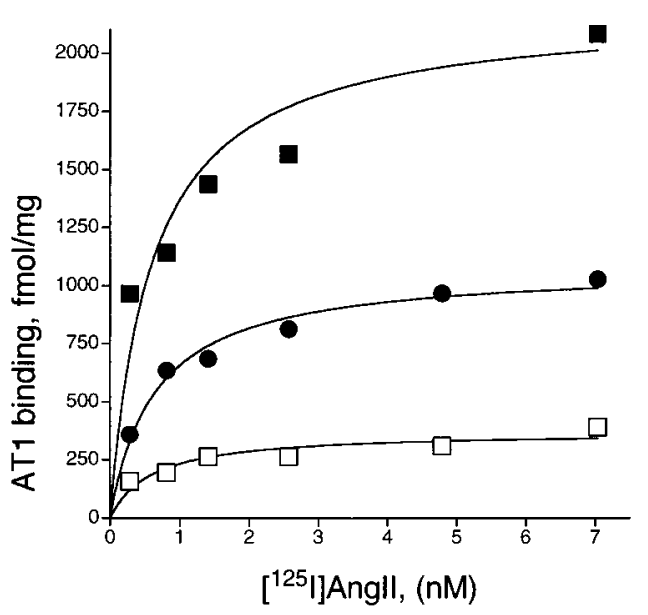

\begin{tabular}{|l|lr|}
\hline \multicolumn{1}{|c|}{ Steroid } & Bmax, fmol/mg & Kd, $\mathrm{nM}$ \\
\hline Vehicle & $419 \pm 55$ & $0.57 \pm 0.05$ \\
CORT $(50 \mathrm{nM})$ & $870 \pm 181^{*}$ & $0.70 \pm 0.08$ \\
DEX $(5 \mathrm{nM})$ & $1962 \pm 217^{*}$ & $0.59 \pm 0.13$ \\
\hline
\end{tabular}

Figure 2 Representative saturation isotherm. WB cells were treated with vehicle $(\square)$, corticosterone (50 nM) (CORT, - ) or dexamethasone ( $5 \mathrm{nM}$ ) (DEX, $\mathbf{0})$ for $20 \mathrm{~h}$ before harvest.

Saturation binding was done with concentrations of ${ }^{125}$ I-Angll from $0.3 \mathrm{nM}$ to $7 \mathrm{nM}$. Nonspecific binding was determined with unlabelled Sarlle $(1 \mu \mathrm{M})$. Triplicate values were averaged and calculated as specific $\mathrm{fmol} / \mathrm{mg}$ protein. The Bmax and $K_{\mathrm{d}}$ values shown in the table represent data from three separate experiments; mean \pm S.D. ${ }^{*} P<0 \cdot 05$.

effects of corticosterone and dexamethasone on AT1 binding resulted from an increased number of AT1 receptors rather than a change in the affinity of the receptor for the ${ }^{125} \mathrm{I}$-AngII ligand. Saturation binding showed that treatment with corticosterone and dexamethasone increased the number of AT1 receptors as reflected by a significant increase in the Bmax $(F[2,6]=68 \cdot 2, P<0 \cdot 0001, n=3)$ without changing the $K_{\mathrm{d}}$ of the AT1 receptor (Fig. 2; graph and accompanying table). The effect of dexamethasone on Bmax was greater than the effect of corticosterone on Bmax and could result from the greater affinity of dexamethasone for the GR (McEwen et al. 1986), as the dose of dexamethasone used exceeded its $\mathrm{EC}_{50}$, whereas the dose of corticosterone was comparable to its $\mathrm{EC}_{50}$.

As both corticosterone and dexamethasone significantly increased AT1 binding (Fig. 1), and as either can interact with both the MR and GR (Reul \& De Kloet 1985), we next determined which receptors mediate the increase in AT1 binding. Cells were treated with the MR antagonist, RU $28318(1 \mu \mathrm{M})$, or the GR antagonist, RU 38486 $(1 \mu \mathrm{M})$, along with corticosterone $(50 \mathrm{nM})$ or dexamethasone $(5 \mathrm{nM})$. These doses of steroid were used in the antagonist experiments because it was necessary to show that the stimulatory effect of dexamethasone and

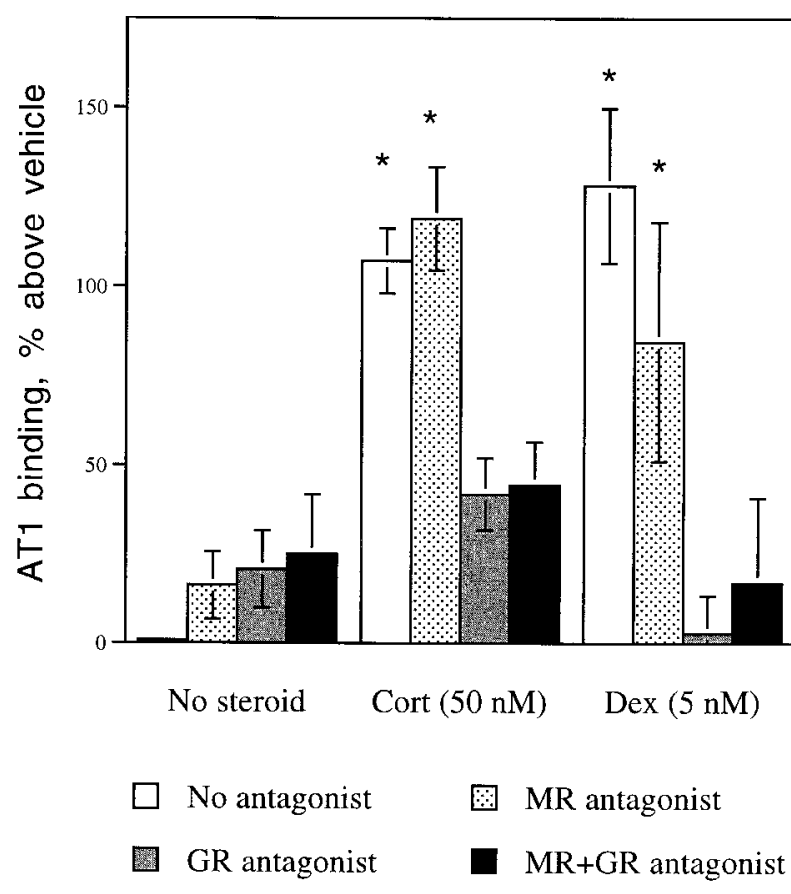

Figure 3 Effects of corticosterone (Cort) and dexamethasone (Dex) on AT1 binding are via GR. WB cells were pretreated with vehicle (no antagonist), MR antagonist RU $28318(1 \mu \mathrm{M})$, the GR antagonist RU $38486(1 \mu \mathrm{M})$, or both, for $2 \mathrm{~h}$ before addition of vehicle (no steroid), dexamethasone $(5 \mathrm{nM})$ or corticosterone $(50 \mathrm{nM})$. Cells were harvested $20 \mathrm{~h}$ later and prepared for $0.5 \mathrm{nM}$ ${ }^{125} \mathrm{I}$-Angll binding. Binding is presented as \% increase (mean \pm S.D.) above that achieved with vehicle. Baseline values for vehicle was $305 \pm 53 \mathrm{fmol} / \mathrm{mg}$ protein, $n=6,{ }^{\star} P<0.05$ compared with vehicle.

corticosterone on AT1 binding could be significantly decreased with a GR antagonist. Using lower (submaximal) doses may have not illustrated this result. The MR antagonist RU28318, GR antagonist RU 38486, or both antagonists together, had no significant effect on AT1 binding compared with vehicle treatment (Fig. 3). Corticosterone increased AT1 binding by $107 \pm 9 \%$ over vehicle treatment $(P<0 \cdot 05$ compared with vehicle, $n=6)$. This stimulatory effect was not significantly changed by treatment with the MR antagonist, RU 28318 $(119 \pm 14 \% ; P<0 \cdot 05)$. However, treatment with RU 38486 significantly decreased AT1 binding to $41 \pm 10 \%$, which was not significantly different from the effect of GR antagonist RU 38486 or vehicle alone. In addition, treatment with both RU 28318 and RU 38486 did not further affect AT1 binding versus the RU 38486 alone. This indicates that the stimulatory effect of corticosterone on AT1 binding is mediated by the GR exclusively. Similarly, cells treated with dexamethasone $(5 \mathrm{nM})$ alone showed a $128 \pm 21 \%$ increase in AngII binding over vehicle treatment $(P<0 \cdot 05)$. This increase in AT1 binding was not significantly affected $(84 \pm 33 \%)$ by the presence of RU 28318. However, treatment with RU 38486 


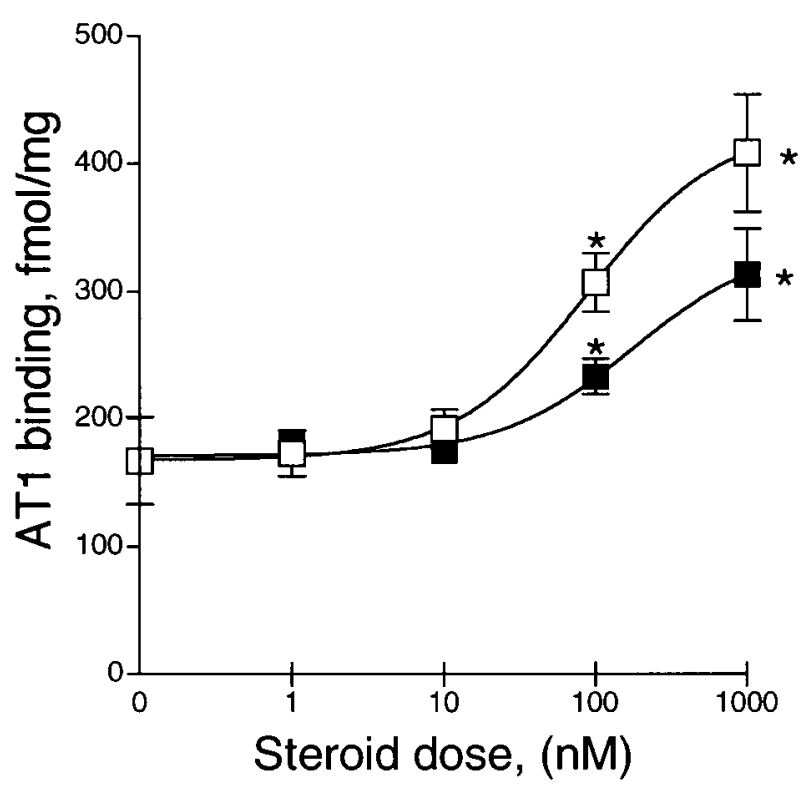

Figure 4 Effects of aldosterone $(\square)$ and DOCA ( $\mathbf{\square})$ on AT1 binding. Dose-response curve of aldosterone and DOCA on $0.5 \mathrm{nM}^{125}$ I-Angll binding. WB cells were treated with steroid at doses of 1-1000 $\mathrm{nM}$ for $20 \mathrm{~h}$ before harvest. The data are presented as AT1 binding in $\mathrm{fmol} / \mathrm{mg}$ protein and represent the mean \pm S.D. of three experiments, ${ }^{*} P<0 \cdot 05$ compared with vehicle.

prevented the increase in AT1 binding $(3 \pm 10 \%)$, whereas the effect of treatment with both RU 28318 and RU 38486 was not different than that with RU 38486 alone (17 $\pm 23 \%$ increase over vehicle). Thus, as with corticosterone, the stimulatory effect of dexamethasone on AT1 binding is mediated by the GR and not by the MR.

We next examined the role of mineralocorticoids in this system and whether they act cooperatively with glucocorticoids to modulate the effects on AT1 binding or function. WB cells were treated with increasing doses of two mineralocorticoids, aldosterone and DOCA at doses of 1 , 10, 100, and $1000 \mathrm{nM}$ for $20 \mathrm{~h}$ before harvest. DOCA possesses mostly mineralocorticoid activity, with some glucocorticoid activity, and may have a longer half-life than aldosterone (Vallee et al. 1995). Cells treated with aldosterone showed no increase in AT1 binding at the lower doses, but at the supraphysiological doses of $100 \mathrm{nM}$ and $1 \mu \mathrm{M}$, they increased AT1 binding by $90 \%$ and 152\%, respectively (Fig. 4). Similarly, DOCA treatment increased AT1 binding, but only at the highest doses of $100 \mathrm{nM}$ and $1 \mu \mathrm{M}$, with which binding was increased by $40 \%$ and $87 \%$, respectively. Treatment with higher doses of aldosterone or DOCA $(10 \mu \mathrm{M})$ resulted in AT1 binding equivalent to that of $1 \mu \mathrm{M}$ doses (data not shown). Also, at the $100 \mathrm{nM}$ and $1 \mu \mathrm{M}$ doses, aldosterone treatment elicited greater AT1 binding than DOCA, although the increased potency (aldosterone $\mathrm{EC}_{50}=89 \pm 14 \mathrm{nM}$; DOCA $\left.\mathrm{EC}_{50}=221 \pm 73, n=3\right)$ did not reach the level of statistical significance $(P=0 \cdot 15)$.

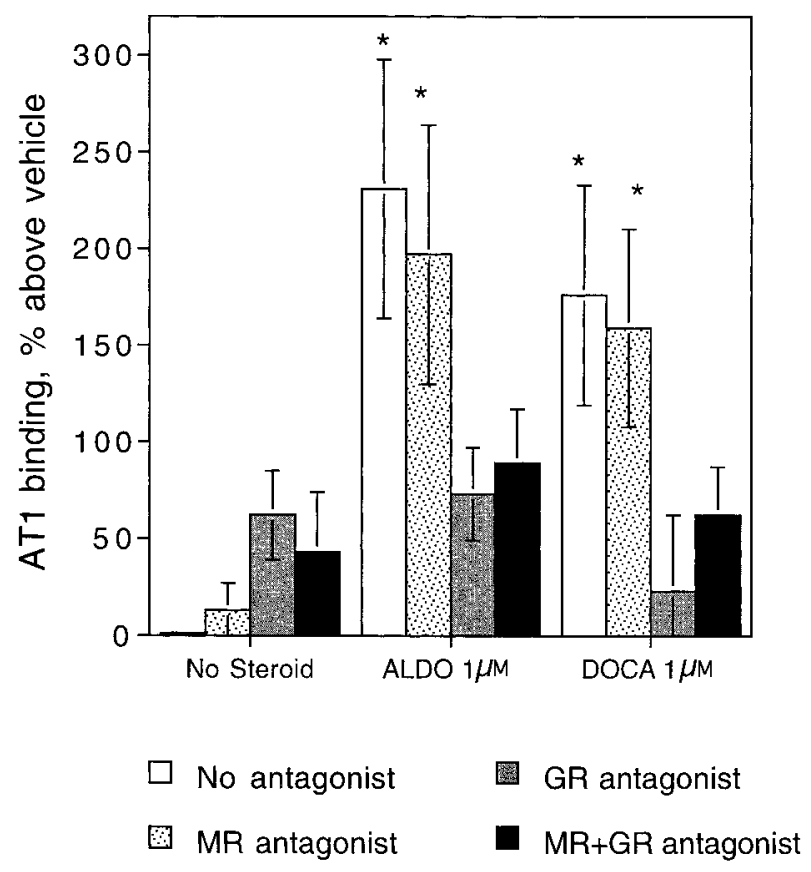

Figure 5 Effects of aldosterone (ALDO) and DOCA on AT1 binding are via GR. WB cells were pretreated with vehicle (no antagonist), MR antagonist RU $28318(10 \mu \mathrm{M})$, the GR antagonist RU $38486(10 \mu \mathrm{M})$, or both, for $2 \mathrm{~h}$ before addition of vehicle (no steroid), aldosterone $(1 \mu \mathrm{M})$ or DOCA $(1 \mu \mathrm{M})$. Cells were harvested $20 \mathrm{~h}$ later and prepared for $0.5 \mathrm{nM}{ }^{125}$ I-Angll binding Binding is presented as $\%$ increase (mean \pm S.D.) over vehicle. Baseline values for vehicle was $141 \pm 15 \mathrm{fmol} / \mathrm{mg}$ protein, $n=3$, ${ }^{*} P<0 \cdot 05$ compared with vehicle.

Although physiological doses of aldosterone and DOCA are believed to mediate their effect via the MR, both of these steroids can bind to the GR at pharmacological doses (Claire et al. 1989, Schmidt et al. 1993). Because high doses of aldosterone and DOCA were necessary to increase AT1 binding significantly, the next experiment determined if this effect was mediated by MR or GR. Cells were treated with the MR antagonist RU 28318 $(10 \mu \mathrm{M})$ and the GR antagonist RU $38486(10 \mu \mathrm{M})$, along with $1 \mu \mathrm{M}$ aldosterone or DOCA - doses that stimulated AT1 binding (Fig. 4). In this experiment, a $10 \mu \mathrm{M}$ antagonist dose was used, rather than $1 \mu \mathrm{M}$ antagonist (Fig. 3), because higher doses of steroid agonist were used. The MR antagonist RU $28318(10 \mu \mathrm{M})$ or the GR antagonist RU $38486(10 \mu \mathrm{M})$, given alone or together, did not significantly increase AT1 binding compared with vehicle (Fig. 5). Treatment with $1 \mu \mathrm{M}$ aldosterone increased AT1 binding over vehicle by $231 \pm 67 \%$ $(P<0 \cdot 05$ compared with vehicle, $n=3)$. Similarly, administration of $1 \mu \mathrm{M}$ DOCA increased AT1 binding over vehicle by $176 \pm 57 \%(P<0 \cdot 05$ compared with vehicle). As shown in Fig. 5, pretreatment of cells with RU 28318 along with $1 \mu \mathrm{M}$ aldosterone or $1 \mu \mathrm{M}$ DOCA did not significantly affect AT1 binding compared with steroid 
alone. However, pretreatment of the cells with RU 38486 significantly decreased aldosterone- or DOCA-induced AT1 binding $(P<0 \cdot 05)$. In addition, treatment with both RU 28318 and RU 38486 did not further affect AT1 binding compared with the inhibitory effect of RU 38486 alone. Thus, the stimulatory effects of high-dose aldosterone and DOCA on AT1 binding are mediated by the GR exclusively.

The subsequent experiments were aimed at determining if aldosterone could act cooperatively with dexamethasone to modulate AT1 binding or AT1-mediated actions. Cells were treated with a dose of aldosterone $(1 \mathrm{nM})$ that primarily interacts with MR only (Reul \& De Kloet 1985), along with two doses of dexamethasone $(1 \mathrm{nM}$ and $5 \mathrm{nM})$. The $1 \mathrm{nM}$ dose represents a submaximal dose of dexamethasone that would allow detection of a potential synergy with aldosterone on AT1 binding. Treatment with aldosterone alone did not increase AT1 binding (aldosterone $1 \mathrm{nM} 182 \pm$ $24 \mathrm{fmol} / \mathrm{mg}$ compared with vehicle $188 \pm 3 \mathrm{fmol} / \mathrm{mg}$; $n=3$ ), similar to the results shown in Fig. 4 . Also, the $76 \%$ increase in AT1 binding after $1 \mathrm{nM}$ dexamethasone treatment $(P<0.05$ compared with vehicle) was not further increased by combined treatment with aldosterone (dexamethasone $1 \mathrm{nM} 330 \pm 24 \mathrm{fmol} / \mathrm{mg}$; aldosterone $(1 \mathrm{nM})+$ dexamethasone $(1 \mathrm{nM}) 315 \pm 27 \mathrm{fmol} / \mathrm{mg})$. Similarly, the $176 \%$ increase in AT1 binding after $5 \mathrm{nM}$ dexamethasone treatment $(P<0.05$ compared with vehicle) was not further increased by combined treatment with aldosterone (dexamethasone $(5 \mathrm{nM}) 520 \pm 37 \mathrm{fmol} /$ $\mathrm{mg}$; aldosterone +dexamethasone $474 \pm 4 \mathrm{fmol} / \mathrm{mg}$ ), indicating that no cooperativity was occurring between the two steroids at the level of AT1 binding.

AngII binding to the AT1 receptor leads to the formation of IP3. We examined if the increase in AT1 receptor seen with dexamethasone leads to an increase in AngIIinduced IP3 formation. Cells were loaded with myo$\left[{ }^{3} \mathrm{H}\right]$ inositol and treated with dexamethasone $(5 \mathrm{nM})$ or vehicle for $20 \mathrm{~h}$, followed by stimulation with AngII. As seen in Fig. 6, there was a main treatment effect, with dexamethasone increasing AngII-stimulated IP3 formation $(F[1,72]=4 \cdot 39, P=0 \cdot 039, n=10)$. However, there was no significant difference in $\mathrm{EC}_{50}$ values between vehicle and dexamethasone treatment (vehicle $\mathrm{EC}_{50}=37 \pm 8 \mathrm{nM}$; dexamethasone $\mathrm{EC}_{50}=92 \pm 38 \mathrm{nM}$ ). Cells also were tested for ${ }^{125} \mathrm{I}$-AngII binding. Dexamethasone increased AT1 binding, which was correlated with an increase in IP3 formation that accompanied the increase in AT1 binding $(r=0.73, P<0 \cdot 05)$.

Although physiological doses of aldosterone did not result in increased AT1 binding (Fig. 4), we examined if aldosterone affected AngII-induced IP3 formation, possibly suggesting a role for aldosterone in AT1 signal transduction. Thus, cells were loaded with $m y o-\left[{ }^{3} \mathrm{H}\right]$ inositol and treated with aldosterone $(1,10,100,1000 \mathrm{nM})$ or vehicle for $20 \mathrm{~h}$, followed by stimulation with AngII.

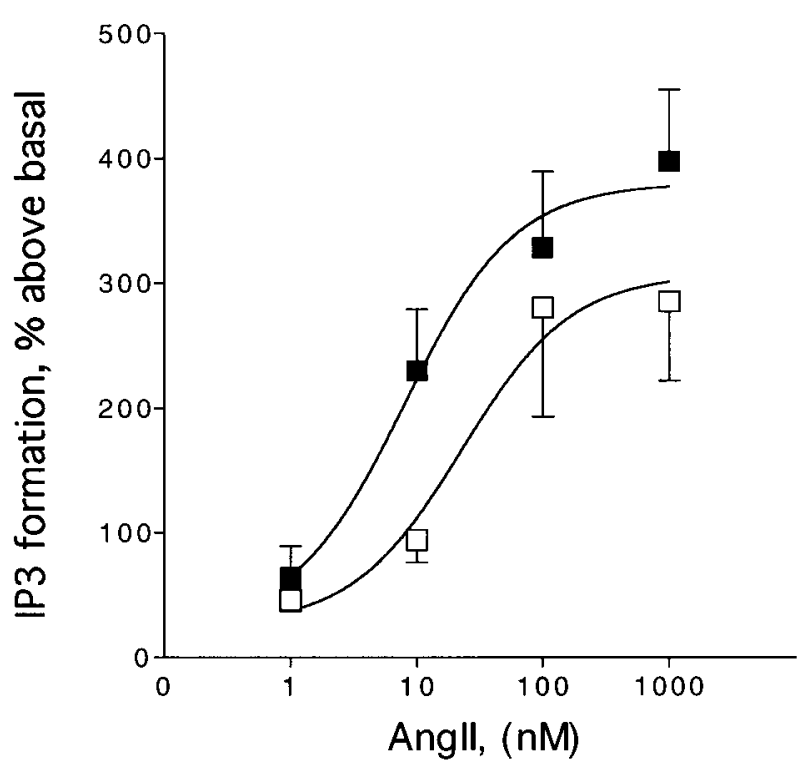

Figure 6 Effect of dexamethasone on Angll-stimulated IP3 formation: dexamethasone treatment leads to an increase in Angll-stimulated IP3 formation. WB cells were loaded with $5 \mu \mathrm{Ci} / \mathrm{ml}$ myo- $\left[{ }^{3} \mathrm{H}\right]$ inositol and were treated with dexamethasone $(5 \mathrm{nM})(\boldsymbol{\square})$ or vehicle $(\square)$ for $20 \mathrm{~h}$. After treatment, cells were stimulated with increasing doses of Angll $(0,1,10,100,1000 \mathrm{nM})$ for $30 \mathrm{~s}$ and assayed for IP3 formation. Values are represented as $\%$ increase in IP3 formation (c.p.m./mg) above basal (no Angll stimulation) of the same treatment. Baseline value for unstimulated vehicle treatment was $135 \pm 37$ c.p.m./mg and was comparable to unstimulated dexamethasone treatment (135 \pm 9 c.p.m./mg), demonstrating that there was no difference in basal IP3 levels. There was a main treatment effect of dexamethasone $(n=10$, $P=0 \cdot 039)$.

Despite a wide range of doses of aldosterone (Table 1), the increase in IP3 formation did not reach statistical significance $(F[4,50]=1 \cdot 74, P=0 \cdot 15, n=3)$. However, it was possible that aldosterone or dexamethasone could synergistically exert post-receptor effects on mediators of AngII signal response, such as IP3 formation. Therefore, cells were loaded with myo- $\left[{ }^{3} \mathrm{H}\right]$ inositol and treated with vehicle, dexamethasone $(5 \mathrm{nM})$, aldosterone $(1 \mathrm{nM})$, or both, followed by AngII-stimulation. Aldosterone treatment alone had no effect on IP3 formation compared with control (Fig. 7). Dexamethasone had a significant stimulatory effect on IP3 formation $(P<0 \cdot 05)$, as was seen previously (Fig. 6). In addition, dexamethasone+ aldosterone stimulated IP3 formation above vehicle $(P<0 \cdot 05)$, but no differently than dexamethasone alone. Also, there was no significant difference in $\mathrm{EC}_{50}$ values between the groups (vehicle, $11 \cdot 6 \pm 3 \mathrm{nM}$; aldosterone, $13 \cdot 5 \pm 2 \cdot 4$; dexamethasone, $19 \cdot 25 \pm 5 \cdot 2$; aldosterone+ dexamethasone, $18 \cdot 7 \pm 4 \cdot 1 ; n=3$ ). In parallel, WB cells also were tested for ${ }^{125} \mathrm{I}$-AngII binding. Consistent with the results in which dexamethasone and aldosterone+ dexamethasone, but not aldosterone alone, increased AT1 
Table 1 Effect of aldosterone on Angll-stimulated IP3 formation: aldosterone treatment does not increase Angll-stimulated IP3 formation. WB cells were loaded with $5 \mu \mathrm{Ci} / \mathrm{ml}$ myo- $\left[{ }^{3} \mathrm{H}\right]$ inositol and were treated with aldosterone $(1 \mathrm{nM}-1 \mu \mathrm{M})$ or vehicle for $20 \mathrm{~h}$. After treatment, cells were stimulated with increasing doses of Angll $(0,1,10,100,1000 \mathrm{nM})$ for $30 \mathrm{~s}$ and assayed for IP3 formation. Values are represented as IP3 formation (c.p.m./mg) above basal (no Angll stimulation) of the same treatment (mean \pm S.D. of three experiments). Baseline values for unstimulated vehicle treatment were comparable to those of the aldosterone treatment groups.

\begin{tabular}{|c|c|c|c|c|c|}
\hline \multirow[b]{3}{*}{ AngII } & \multirow[b]{2}{*}{ Vehicle } & \multicolumn{4}{|c|}{ Aldosterone } \\
\hline & & $1 \mathrm{nM}$ & $10 \mathrm{nM}$ & $100 \mathrm{nM}$ & $1 \mu \mathrm{M}$ \\
\hline & & & & & \\
\hline $1 \mathrm{nM}$ & $8 \pm 29$ & $100 \pm 145$ & $138 \pm 36$ & $199 \pm 66$ & $77 \pm 47$ \\
\hline $10 \mathrm{nM}$ & $214 \pm 22$ & $450 \pm 198$ & $467 \pm 59$ & $429 \pm 22$ & $499 \pm 9$ \\
\hline $100 \mathrm{nM}$ & $871 \pm 27$ & $906 \pm 302$ & $1097 \pm 173$ & $1105 \pm 51$ & $1023 \pm 68$ \\
\hline $1 \mu \mathrm{M}$ & $789 \pm 93$ & $831 \pm 112$ & $1037 \pm 92$ & $965 \pm 31$ & $857 \pm 16$ \\
\hline
\end{tabular}

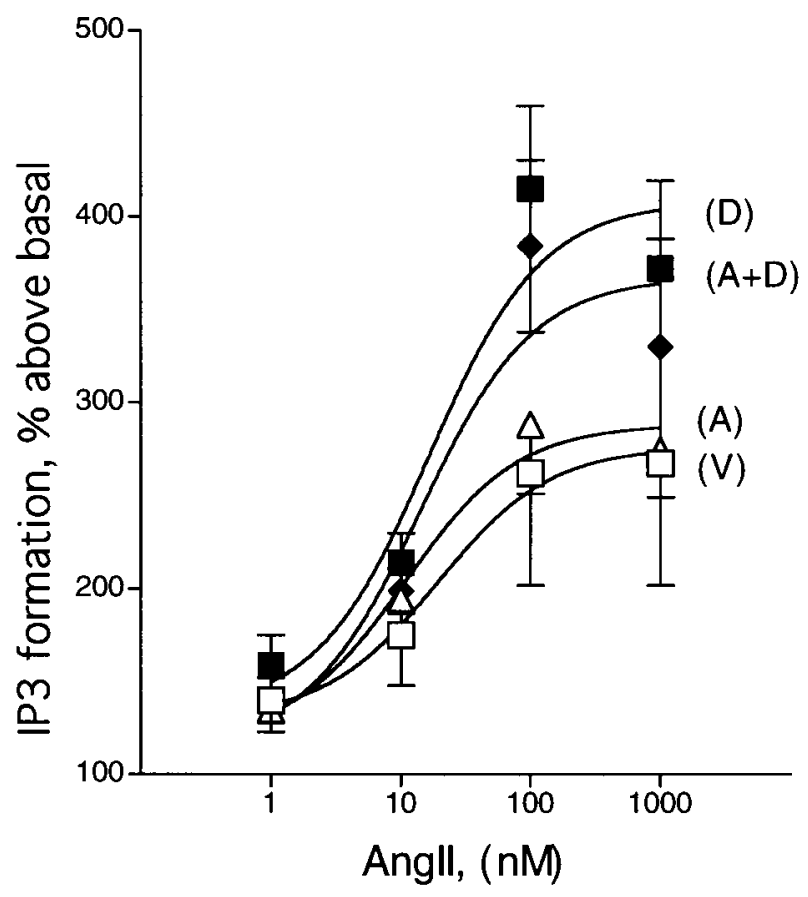

Figure 7 Effect of aldosterone+dexamethasone on Angll-stimulated IP3 formation. Aldosterone treatment does not increase the stimulatory effects of dexamethasone on Angll-stimulated IP3 formation. WB cells were loaded with $5 \mu \mathrm{Ci} / \mathrm{ml}$ myo- $\left[{ }^{3} \mathrm{H}\right]$ inositol and were treated with vehicle $(\mathrm{V}, \square)$, aldosterone $(1 \mathrm{nM})(\mathrm{A}, \triangle)$, dexamethasone $(5 \mathrm{nM})(\mathrm{D}, \mathbf{\square})$, or aldosterone+dexamethasone $(A+D, \diamond)$ for $20 \mathrm{~h}$. After treatment, cells were stimulated with Angll $(0,1,10,100,1000 \mathrm{nM})$ for $30 \mathrm{~s}$ and assayed for IP3 formation. Values are represented as \% increase in IP3 formation (c.p.m./mg) over basal (no Angll stimulation) of the same treatment. Baseline values for unstimulated vehicle treatment were comparable to those of $A, D$, and $\mathrm{A}+\mathrm{D}$ treatment groups. Dexamethasone and dexamethasone+ aldosterone had a significant stimulatory effect on IP3 formation compared with vehicle $(P<0 \cdot 05)$, but no different than dexamethasone alone (mean \pm S.D. of three experiments). binding, there was also an increase in IP3 formation that accompanied the increase in AT1 binding $(r=0 \cdot 87$, $P<0 \cdot 05)$. These data indicate that the stimulatory effect of dexamethasone on IP3 formation was not further affected by aldosterone, indicating the lack of synergy between the two hormones at the level of IP3 formation.

The AT1 receptor is coupled to the G-protein, Gq, which mediates AngII-induced IP3 formation (Taylor et al. 1990, Langlois et al. 1994). To determine the effect of adrenal steroids on factors distal to the receptor, Western blot analysis was used to determine the effects of adrenal steroids on $\mathrm{Gq}$ expression. Cells were treated with vehicle, aldosterone $(1 \mathrm{nM})$, dexamethasone $(5 \mathrm{nM})$ or both, and prepared for immunodetection using antisera with equal specificity to $\mathrm{Gq}_{\alpha 11}$ and $\mathrm{Gq}_{\alpha \mathrm{q}}$ (Lounsbury et al. 1993). As shown in Fig. 8, a $42 \mathrm{kDa}$ band was detected, but there was no significant difference between any of the treatment groups.

Given the absence of an MR effect, RT-PCR was used to demonstrate the presence of $\mathrm{MR}$ in WB cells. Rat anterior pituitary tissue was used as a positive control (Reul et al. 1990, 1994, Rosenfeld et al. 1990, Turner 1990, Rothuizen et al. 1993, Schobitz et al. 1994, Smith et al. 1994, McCormick et al. 1998). The MR (695 bp band) was expressed in WB cells and in the anterior pituitary (Fig. 9).

\section{Discussion}

The AT1 receptor mediates many physiological and behavioral actions of AngII (Bottari et al. 1993). Both mineralocorticoids and glucocorticoids regulate components of the renin-angiotensin system, including the AT1 receptor. The aim of this study was to examine the direct effects of adrenal steroids on AT1 binding and post-receptor signalling mechanisms in WB cells. First, corticosterone and dexamethasone increased the number 


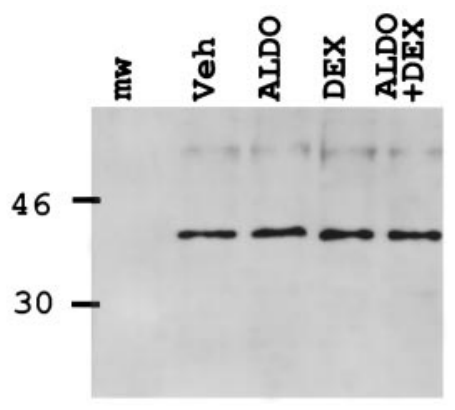

Densitometry of Gq Immunoblot

\begin{tabular}{|l|l|}
\hline Treatment group & Optical density \\
\hline Vehicle & $159 \pm 13$ \\
ALDO $(1 \mathrm{nM})$ & $160 \pm 17$ \\
DEX $(5 \mathrm{nM})$ & $161 \pm 8$ \\
ALDO + DEX & $155 \pm 17$ \\
\hline
\end{tabular}

Figure 8 Immunoblot of Gq. WB cells were treated with vehicle (Veh), aldosterone (ALDO) (1 nM), dexamethasone (DEX) (5 nM), or ALDO+DEX for $20 \mathrm{~h}$ before harvest. Samples were separated by $10 \%$ SDS-PAGE, immunoblotted, and detected with a rabbit anti-Gq antibody. As shown, a $42 \mathrm{kDa}$ band was detected. Molecular mass markers (mw) are shown. The table represents specific optical density measurements from four separate experiments (mean \pm S.D.).

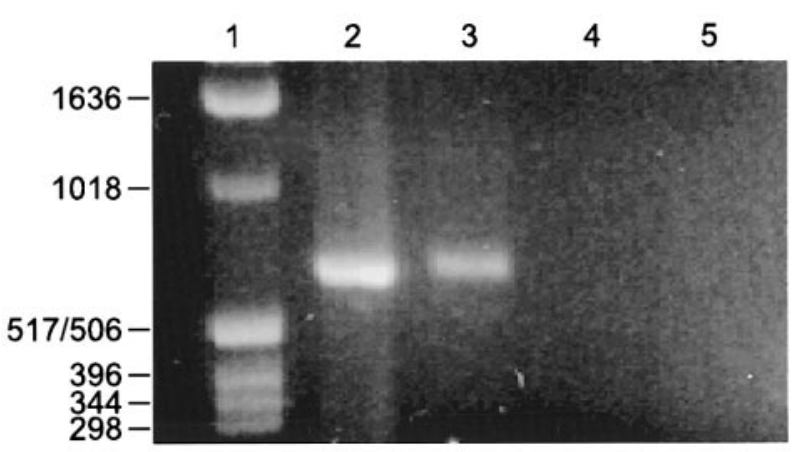

Figure 9 Ethidium bromide-stained agarose gel showing MR PCR product, $695 \mathrm{bp}$, after RT-PCR amplification of CDNA from WB cells and from rat anterior pituitary gland. Lane 1, $1 \mathrm{~kb}$ DNA ladder molecular weight marker; lane 2, Pituitary MR; lane 3, WB cell MR; lane 4, Pituitary negative control (no reverse transcriptase); Lane 5, WB cell negative control (no reverse transcriptase).

of AT1 receptors by activating the GR, but not the MR. Functionally, this led to an increase in AngII-induced IP3 formation, which can result in increases in intracellular calcium and distal signalling cascades (Berridge 1993). Also analyzed was the effect of aldosterone, the endogenous mineralocorticoid, and DOCA, a synthetic mineralocorticoid used in vitro and in vivo studies of AngII receptor regulation (Sumners \& Fregly 1989, Vallee et al. 1995). Neither aldosterone nor DOCA increased AT1 binding at physiological levels, but both stimulated AT1 binding at the highest doses. However, using specific MR and GR antagonists, it was apparent that aldosterone and DOCA stimulated AT1 binding by only activating the GR, and not the MR. Furthermore, although high-dose mineralocorticoids increased AT1 binding, AngII-induced IP3 formation was not significantly affected. This may result from insufficient coupling of the AT1 receptor to its post-receptor signalling factors. An MR-mediated effect was not detected despite MR expression in these cells, as detected by RT-PCR (Fig. 9). This technique closely correlates with the presence of functional nuclear steroid hormone receptor protein (Castagnetta \& Caruba 1995, Bodine et al. 1997, Malayer \& Woods 1998, Robinson et al. 1998), such as the MR in the anterior pituitary (Reul et al. 1990, 1994, Rosenfeld et al. 1990, Turner 1990, Rothuizen et al. 1993, Schobitz et al. 1994, Smith et al. 1994, McCormick et al. 1998).

Adrenal steroids regulate multiple components of the renin-angiotensin system, including angiotensinogen (Deschepper \& Flaxman 1990, Bunnemann et al. 1993, Riftina et al. 1995, Ryan et al. 1997) and angiotensinconverting enzyme (Mendelsohn et al. 1982), both of which could generate more AngII ligand. In addition, the physiological and behavioral actions of AngII can be modulated by mineralocorticoids (Epstein 1982, Fluharty \& Epstein 1983, Zhang et al. 1984, Wilson et al. 1986, King et al. 1988) and glucocorticoids (Krakoff et al. 1975, Whitworth 1987, Ganesan \& Sumners 1989, Sumners et al. 1991) at the level of the AT1 receptor (Schiffrin et al. 1984, Wilson et al. 1986, Sumners \& Fregly 1989, Ullian et al. 1992). Furthermore, glucocorticoids enhance mineralocorticoid-induced actions (Ma et al. 1993, Zhang et al. 1993). To examine the cellular basis of this synergy, cells were treated concomitantly with $5 \mathrm{nM}$ dexamethasone, a concentration that augmented AT1 binding and IP3 formation, together with $1 \mathrm{nM}$ aldosterone, a concentration that primarily activates MR (Reul \& De Kloet 1985). However, this combination did not further enhance the effect of dexamethasone alone on binding. It was possible that aldosterone and dexamethasone acted synergistically at post-receptor mechanisms, such that a direct effect on AT1 signalling mechanisms could further amplify AngII stimulation. However, aldosterone $(1 \mathrm{nM})$ did not further augment the effect of dexamethasone alone on AngII-induced IP3 formation. We also examined the expression of Gq, which mediates AngII-induced IP3 formation from the AT1 receptor (Taylor et al. 1990, Fluharty \& Sakai 1995). The results confirmed that dexamethasone did not increase Gq expression (Sato et al. 1994), and neither did the other steroid treatments. Thus, no synergy between aldosterone and dexamethasone was seen at the level of AT1 binding, Gq expression, or IP3 formation. However, we cannot exclude the possibility 
that aldosterone and dexamethasone act together to regulate signalling factors distal to Gq or IP3 formation or other signalling molecules, such as cyclic AMP, which decreases after AngII stimulation (reviewed by Fluharty \& Sakai 1995).

At physiological doses $\left(K_{\mathrm{d}} \sim 0.5 \mathrm{nM}\right)$, mineralocorticoids activate the MR and increase AT1 binding (Sumners \& Fregly 1989, DeNicola et al. 1993, Shelat et al. 1998). However, by using specific MR and GR antagonists, it has been shown that pharmacological doses of mineralocorticoids $\left(K_{\mathrm{d}} \sim 20-50 \mathrm{nM}\right)$ bind the GR and mimic glucocorticoid activation (Reul \& De Kloet 1985, Claire et al. 1989, Schmidt et al. 1993). Similar cases of GR activation by supraphysiological concentrations of mineralocorticoids have been reported, including sodium transport in A6 kidney cells, which express both the MR and GR (Claire et al. 1989, Schmidt et al. 1993), inhibition of glucose transport in primary neuronal and glial cell cultures (Horner et al. 1990), modulation of microglial morphology (Tanaka et al. 1997), and regulation of endothelin and AngII binding in vascular smooth muscle cells (Provencher et al. 1995). In the latter study, the increase in AngII binding in vascular smooth muscle cells after $100 \mathrm{nM}$ aldosterone treatment was only partially blocked by the GR antagonist, RU 38486 (Provencher et al. 1995). Although this study did not look at the effect of MR antagonists and GR antagonists, alone and together, on suppressing the aldosterone effect on AngII binding, it would have been interesting to see if the combined treatment with the GR and MR antagonist together completely suppressed the aldosterone effect on AngII binding, thereby showing that the aldosterone effect was mediated partly by MR and partly by GR. In contrast, the present study showed that the stimulatory effect of supraphysiological doses of both aldosterone and DOCA was completely blocked by the GR antagonist, RU 38486 (Fig. 5). Furthermore, treatment with both the MR antagonist RU28318 and the GR antagonist RU 38486 together did not further affect AT1 binding compared with the inhibitory effect of RU 38486 alone (Fig. 5). Thus the stimulatory effects of high-dose aldosterone and DOCA on AT1 binding were mediated by the GR exclusively. Another study showed that a $1 \mu \mathrm{M}$ dose of aldosterone increased AngII receptor binding and AngII-induced IP3 response in cultured vascular smooth muscle cells (Ullian et al. 1992). This effect may also have reflected GR activation because, in these same cells, dexamethasone increased AngII receptor binding (Sato et al. 1994) and AngII-induced IP3 formation (Sato et al. 1992) by acting at the GR. In the present study, dexamethasone, corticosterone, and high-dose aldosterone and DOCA increased AT1 binding by acting at the GR.

There are several possible reasons why activation of MR did not increase AT1 binding in this study. This result occurred despite the presence of MR mRNA detected by RT-PCR (see above). First, at low concentrations (1 and $10 \mathrm{nM}$ ), aldosterone and DOCA may have been metabolized to inactive compounds. Secondly, there may have been insufficient MR protein, because of translational or post-translational effects. Consequently, the levels of GR may have far exceeded those of MR, as is true in many tissues (McEwen et al. 1986), and, therefore, activation of the MR may not have been detected. In this case, because of the lower affinity of aldosterone for GR (Claire et al. 1989, Schmidt et al. 1993), only high mineralocorticoid concentrations could activate GR and increase AT1 binding. Future studies will also examine the effects of mineralocorticoid and glucocorticoid on the relative levels of MR and GR after steroid treatment. Lastly, it is possible that the necessary repertoire of cell-specific transcriptional factors was not present for MR-mediated actions on AT1 binding.

Several lines of evidence suggest that steroids act genomically to modulate AT1 receptors. First, the promoter region of the AT1A receptor, the predominant AT1 receptor subtype in liver cells, contains an active glucocorticoid response element (Pearce \& Yamamoto 1993, Guo et al. 1995). Secondly, in the WB cells (Shelat, unpublished data) and in other systems (Provencher et al. 1995, Wintersgill et al. 1995), the time-course of glucocorticoid action is consistent with steroids acting genomically (Tsai \& O'Malley 1994). Thirdly, the steroid effects can be abolished with inhibitors of protein synthesis (Ullian et al. 1992). Fourthly, the stimulatory effects of corticosterone, dexamethasone and high-dose aldosterone and DOCA can be suppressed by blocking the GR, a known nuclear transcription factor (Carson-Jurica et al. 1990). Lastly, adrenal steroid effects on AT1 binding are accompanied by parallel changes in AT1 RNA (Sato et al. 1994, Aguilera et al. 1995, Wintersgill et al. 1995). Thus the changes in AT1 binding seen in this study probably reflect a genomic action of steroids in these cells.

The present study was conducted in WB cells - a homogeneous liver epithelial cell population that exclusively expresses the AT1 receptor subtype. Like other cell types that express the AT1 receptor, they can respond to glucocorticoids (because of the ubiquitous expression of GR (McEwen et al. 1986)), and they respond to AngII stimulation by increasing IP3 formation (Bokkala \& Joseph 1997). However, the WB cells may not precisely represent the cellular environment in all cell types, as another study showed that glucocorticoid treatment in a human hepatoma cell line decreased AT1 receptor expression (Wintersgill et al. 1995). This disparity suggests that cell-specific factors are necessary for steroid receptor activation, which may account for the failure of physiological doses of mineralocorticoids to modulate AT1 binding or IP3 formation. This study shows that activation of the GR can amplify AngII-mediated actions by increasing the expression of AT1 receptors and IP3 formation. These effects may provide the cellular basis of how glucocorticoids enhance AngII-mediated physiological and behavioral actions. 


\section{Acknowledgements}

We thank Jennifer L King for help with the binding assays and proofreading of the manuscript, Derek Daniels for immunoblot graphics, John Hines for assistance with inositol triphosphate assays, Lori R Kisley for RT-PCR work, and Randall R Sakai for assistance with cell culture. L M F-C and S J F were supported by MH43787 and DK52018.

\section{References}

Aguilera G, Young WS, Kiss A \& Bathia A 1995 Direct regulation of hypothalamic corticotropin releasing hormone neurons by angiotensin II. Neuroendocrinology 61 437-444.

Berridge MJ 1993 Inositol trisphosphate and calcium signalling. Nature 361 315-325.

Bodine PV, Green J, Harris HA, Bhat RA, Stein GS, Lian JB \& Komm BS 1997 Functional properties of a conditionally phenotypic, estrogen-responsive, human osteoblast cell line. Journal of Cellular Biochemistry 65 368-387.

Bokkala S \& Joseph SK 1997 Angiotensin II-induced down-regulation of inositol trisphosphate receptors in WB rat liver epithelial cells. Journal of Biological Chemistry 272 12454-12461.

Bottari SP, de Gasparo M, Steckelings UM \& Levens NR 1993 Angiotensin II receptor subtypes: characterization, signalling mechanism, and possible physiological implications. Frontiers in Neuroendocrinology 14 123-171.

Bunnemann B, Lippoldt A, Aguirre JA, Cintra A \& Metzger R 1993 Glucocorticoid regulation of angiotensinogen gene expression in discrete areas of the male rat brain. Neuroendocrinology 57 856-862.

Carson-Jurica MA, Schrader WT \& O'Malley BW 1990 Steroid receptor family: structure and functions. Endocrine Reviews $\mathbf{1 1}$ 210-220.

Castagnetta LA \& Caruba G 1995 Human prostate cancer: a direct role for oestrogens. Ciba Foundation Symposium 191 269-286.

Claire M, Machard B, Lombes M, Oblin ME \& Bonvalet JP 1989 Aldosterone receptors in A6 cells: physicochemical characterization and autoradiographic study. American Journal of Physiology 257 C665-C677.

DeNicola AF, Seltzer A, Tsutsumi K \& Saavedra JM 1993 Effects of deoxycorticosterone acetate (DOCA) and aldosterone on Sar1Angiotensin II binding and angiotensin-converting enzyme binding sites in brain. Cellular and Molecular Neurobiology 13 529-539.

Deschepper CF \& Flaxman M 1990 Glucocorticoid regulation of rat diencephalon angiotensinogen production. Endocrinology 126 963-970.

Epstein AN 1982 Mineralocorticoids and cerebral angiotensin may act together to produce sodium appetite. Peptides 3 493-494.

Fluharty SJ \& Epstein AN 1983 Sodium appetite elicited by intracerebroventricular infusion of angiotensin II in the rat. II. Synergistic interaction with mineralocorticoids. Behavioural Neuroscience 97 746-758.

Fluharty SJ \& Sakai RR 1995 Behavioral and cellular analysis of adrenal steroid and angiotensin interactions mediating salt appetite. In Progress in Psychobiology and Physiological Psychology, vol 16, pp 121-130. Eds SJ Fluharty, AR Morrison, JM Sprague \& E Stellar. San Diego: Academic Press.

Ganesan R \& Sumners C 1989 Glucocorticoids potentiate the dipsogenic action of angiotensin II. Brain Research 499 121-130.

Guo DF, Uno S, Ishihata A, Nakamura N \& Inagami T 1995 Identification of a cis-acting glucocorticoid responsive element in the rat angiotensin II type 1A promoter. Circulation Research $\mathbf{7 7}$ 249-257.
Horner HC, Packan DR \& Sapolsky RM 1990 Glucocorticoids inhibit glucose transport in cultured hippocampal neurons and glia. Neuroendocrinology 52 57-64.

King SJ, Harding JW \& Moe KE 1988 Elevated salt appetite and brain binding of angiotensin II in mineralocorticoid-treated rats. Brain Research 448 140-149.

Krakoff LR, Selvadurai R \& Sutter E 1975 Effect of methylprednisolone upon arterial pressure and the renin angiotensin system in the rat. American Journal of Physiology 228 613-617.

Langlois D, Ouali R, Berthelon MC, Derrien A \& Saez JM 1994 Regulation by growth factors of angiotensin II type- 1 receptor and the $\alpha$ subunit of Gq and G11 in bovine adrenal cells. Endocrinology 135 480-483.

Lounsbury KM, Schlegel B, Poncz M, Brass LF \& Manning DR 1993 Analysis of $\mathrm{Gz}$ alpha by site-directed mutagenesis. Sites and specificity of protein kinase C-dependent phosphorylation. Journal of Biological Chemistry 268 3494-3498.

Ma LY, McEwen BS, Sakai RR \& Schulkin J 1993 Glucocorticoids facilitate mineralocorticoid-induced sodium intake in the rat. Hormones and Behavior 27 240-250.

McCormick CM, Furey BF, Child M, Sawyer MJ \& Donohue SM 1998 Neonatal sex hormones have 'organizational' effect on the hypothalamic-pituitary-adrenal axis of male rats. Developmental Brain Research 105 295-307.

McEwen BS, De Kloet E \& Rostene W 1986 Adrenal steroid receptors and actions in the nervous system. Physiological Reviews $\mathbf{6 6}$ $1121-1188$.

Malayer JR \& Woods VM 1998 Developments of oestrogen receptor expression and hormone response in the uterus of the bovine fetus. Journal of Reproduction and Fertility 112 289-300.

Mendelsohn FA, Lloyd CJ, Kachel C \& Funder JW 1982 Induction by glucocorticoids of angiotensin converting enzyme production from bovine endothelial cells in culture and rat lung in vivo. Journal of Clinical Investigation 70 684-692.

Patel PD, Sherman TG, Goldman DJ \& Watson SJ 1989 Molecular cloning of a mineralocorticoid (type I) receptor complementary DNA from rat hippocampus. Molecular Endocrinology 3 1877-1885.

Pearce D \& Yamamoto KR 1993 Mineralocorticoid and glucocorticoid receptor activities distinguished by nonreceptor factors at a composite response element. Science 259 1161-1165.

Provencher PH, Saltis J \& Funder JW 1995 Glucocorticoids but not mineralocorticoids modulate endothelin-1 and angiotensin II binding in SHR vascular smooth muscle cells. Journal of Steroid Biochemistry and Molecular Biology 52 219-225.

Reul JMHM \& De Kloet ER 1985 Two receptor systems for corticosterone in rat brain: microdistribution and differential occupation. Endocrinology 133 1941-1950.

Reul JMHM, De Kloet ER, van Fluijs FJ, Rijnberk A \& Rothuizen J 1990 Binding characteristics of mineralocorticoid and glucocorticoid receptors in dog brain and pituitary. Endocrinology 127 907-915.

Reul JMHM, Labeur MS, Grigoriadis DE, De Souza EB \& Holsboer F 1994 Hypothalamic-pituitary-adrenocortical axis changes in the rat after long-term treatment with the reversible monoamine oxidase-A inhibitor moclobemide. Neuroendocrinology 60 509-519.

Riftina F, Angulo J, Pompei P \& McEwen BS 1995 Regulation of angiotensinogen gene expression in the rat forebrain by adrenal steroids and relation to salt appetite. Molecular Brain Research 33 201-208.

Robinson AM, Kern RC, Foster JD, Fong KJ \& Pitovski DZ 1998 Expression of glucocorticoid receptor mRNA and protein in the olfactory mucosa: physiologic and pathophysiologic implications. Laryngoscope 108 1238-1242.

Rosenfeld P, Sutanto W, Levine S \& de Kloet ER 1990 Ontogeny of mineralocorticoid (type 1) receptors in brain and pituitary: an in vivo autoradiographical study. Developmental Brain Research $\mathbf{5 2}$ $57-62$. 
Rothuizen J, Reul JMHM, van Fluijs FJ, Mol JA, Rijnberk A \& De Kloet ER 1993 Increased neuroendocrine reactivity and decreased mineralocorticoid receptor-binding capacity in aged dogs. Endocrinology 132 161-168.

Ryan MC, Shen PJ \& Gundlach AL 1997 Angiotensinogen and natriuretic peptide mRNAs in rat brain: localization and differential regulation by adrenal steroids in hypothalamus. Peptides 18 495-504.

Sato A, Suzuki H, Iwaita Y, Nakazato Y, Kato H \& Saruta T 1992 Potentiation of inositol trisphosphate production by dexamethasone. Hypertension 19 109-115.

Sato A, Suzuki H, Murakami M, Nakazato Y, Iwaita Y \& Saruta T 1994 Glucocorticoid increases angiotensin II type 1 receptor and its gene expression. Hypertension 23 25-30.

Schiffrin EL, Gutkowska J \& Genest J 1984 Effect of angiotensin II and deoxycorticosterone infusion on vascular angiotensin II receptors in rats. American Journal of Physiology 246 H608-H614.

Schmidt TJ, Husted RF \& Stokes JB 1993 Steroid hormone stimulation of $\mathrm{Na}+$ transport in A6 cells is mediated via glucocorticoid receptors. American Journal of Physiology 264 C875-C884.

Schobitz B, Sutanto W, Carey MP, Holsboer F \& De Kloet ER 1994 Endotoxin and interleukin 1 decrease the affinity of hippocampal mineralocorticoid (type I) receptor in parallel to activation of the hypothalamic-pituitary-adrenal axis. Neuroendocrinology 60 124-133.

Seltzer A, Pinto JEB, Viglione PN, Correa FMA, Libertun C, Tsutsumi K, Steele MK \& Saavedra JM 1992 Estrogens regulate angiotensin-converting enzyme and angiotensin receptors in the female rat anterior pituitary. Neuroendocrinology 55 460-467.

Shelat SG, Fluharty SJ \& Flanagan-Cato LM 1998 Adrenal steroid regulation of central angiotensin II receptor subtypes and oxytocin receptors in rat brain. Brain Research 807 135-146.

Smith CC, Omeljaniuk RJ, Whitfield HJ, Aksentijevich S, Fellows MQ, Zelazowska E, Gold PW \& Sternberg EM 1994 Differential minealocorticoid (type 1) and glucocorticoid (type 2) receptor expression in Lewis and Fischer rats. Neuroimmunomodulation 1 66-73.

Sumners C \& Fregly MJ 1989 Modulation of angiotensin II binding sites in neuronal cultures by mineralocorticoids. American Journal of Physiology 256 C121-C129.

Sumners C, Gault TR \& Fregly MJ 1991 Potentiation of angiotensin II-induced drinking by glucocorticoids is a glucocorticoid type II receptor (GR)-mediated event. Brain Research 552 283-290.

Tanaka J, Fujita H, Matsuda S, Toku K, Sakanaka M \& Maeda N 1997 Glucocorticoid- and mineralocorticoid receptors in microglial cells: the two receptors mediate differential effects of corticosteroids. Glia 20 23-37.
Taylor SJ, Smith JA \& Exton JH 1990 Purification from bovine liver membranes of a guanine nucleotide dependent activator of phosphoinositide-specific phospholipase C. Journal of Biological Chemistry 265 17150-17156.

Thornton SN \& Nicolaidis S 1994 Long-term mineralocorticoidinduced changes in rat neuron properties plus interaction of aldosterone and Ang II. American Journal of Physiology 266 R564-R571.

Tsai MJ \& O'Malley BW 1994 Molecular mechanisms of steroid/ thyroid receptor superfamily members. Annual Review of Neuroscience 63 451-486.

Turner B 1990 Sex difference in glucocorticoid binding in rat pituitary is estrogen dependent. Life Science 46 1399-1406.

Ullian ME, Schelling JR \& Linas SL 1992 Aldosterone enhances angiotensin II receptor binding and inositol phosphate responses. Hypertension 20 67-73.

Vallee SM, Grillo CA, Gonzalez S, Cosen-Binker L, DeKloet ER, McEwen BS \& DeNicola AF 1995 Further studies in deoxycorticosterone acetate treated rats: brain content of mineralocorticoid and glucocorticoid receptors and effect of steroid antagonists on salt intake. Neuroendocrinology 61 117-124.

Whitworth JA 1987 Mechanisms of glucocorticoid-induced hypertension. Kidney International 31 1213-1224.

Wilson K, Sumners C, Hathaway S \& Fregly MJ 1986 Mineralocorticoids modulate central angiotensin II receptors in rats. Brain Research 382 87-96.

Wintersgill HP, Warburton P, Bryson SE, Ball SG \& Balmforth AJ 1995 Glucocorticoids regulate the expression of angiotensin AT1 receptors in the human hepatoma cell line, PLC-PRF-5. European Journal of Pharmacology 288 365-371.

Wong PC, Chiu AT, Duncia JV, Herblin WF, Smith RD \& Timmermans PBMWM 1992 Angiotensin II receptor antagonists and receptor subtypes. Trends in Endocrinology and Metabolism 3 211-217.

Zhang DM, Stellar E \& Epstein AN 1984 Together intracranial angiotensin and systemic mineralocorticoid produce avidity for salt in the rat. Physiology and Behavior 32 677-681.

Zhang DM, Epstein AN \& Schulkin J 1993 Medial region of the amygdala involvement in adrenal steroid-induced salt appetite. Brain Research 600 20-26.

Received 10 November 1998

Revised manuscript received 22 January 1999

Accepted 9 April 1999 